\title{
STRUKTUR BAHASA NAMA PEDUSUNAN (KAMPUNG) DI DAERAH ISTIMEWA YOGYAKARTA: KAJIAN ANTROPOLINGUISTIK
}

\author{
Prihadi \\ FBS Universitas Negeri Yogyakarta \\ email: prihadi.uny@gmail.com
}

\begin{abstract}
Abstrak
Penelitian ini bertujuan mendeskripsikan aspek linguistik penamaan pedusunan (kampung) di Daerah Istimewa Yogyakarta. Jenis penelitian ini adalah penelitian kualitatif dengan pendekatan etnografi Spradley. Data penelitian adalah nama pedusunan/kampung, yang dikumpulkan melalui wawancara, observasi, dan dokumentasi. Analisis data menggunakan metode agih dengan teknik bagi unsur langsung dan metode padan dengan teknik referensial. Hasil penelitian sebagai berikut. Pertama, nama pedusunan (kampung) dominan berbentuk kata jadian/bentuk kompleks, di samping temuan baru berbentuk frase dan klausa. Kata jadian berupa bentuk pangkal/dasar ditambah pengimbuhan atau morfem pradasar yang sudah memperoleh pengimbuhan atau pemajemukan. Kedua, nama pedusunan (kampung) dominan berbentuk kata polimorfemis. Ketiga, jumlah suku kata toponim pedusunan (kampung) dominan lebih dari dua suku kata. Keempat, pilihan kata yang banyak digunakan adalah kata-kata sehari-hari. Kelima, nama pedusunan/ kampung di DIY dominan terdiri atas satu kata.
\end{abstract}

Kata kunci: toponim, etnografi, linguistik, sejarah-budaya

\section{THE LANGUAGE STRUCTURES OF HAMLET (VILLAGE) NAMES IN YOGYAKARTA SPECIAL REGION: AN ANTHROPOLINGUISTIC STUDY}

\begin{abstract}
This study aims to describe the linguistic aspects in the names of hamlets (villages) in Yogyakarta Special Region (YSR). This was a qualitative study employing the ethnographic approach by Spradley. The data were hamlet/village names, collected through interviews, observations, and documentation. They were analyzed using the distribution method with the immediate element division technique and the correspondence method with the referential technique. The results of the study are as follows. First, hamlet (village) names are dominated by derivatives/complex forms, besides new findings in the form of phrases and clauses. A derivative is a base/stem with affixation or a proto-morpheme with affixation or compounding. Second, hamlet (village) names are dominated by polymorphemic words. Third, the number of syllables in hamlet (village) toponyms is dominated by more than two syllables. Fourth, the mostly selected words are ordinary words. Fifth, the names of hamlets/villages in YSR dominantly consist of one word.
\end{abstract}

Keywords: toponyms, ethnography, linguistics, history-culture

\section{PENDAHULUAN}

Penamaan berarti berurusan dengan sistem simbol dalam budaya. Sistem simbol yang cocok dengan tujuan penelitian ini adalah simbol linguistik dan simbol budaya yang berkenaan dengan nama-nama dusun/pedusunan/kampung dari sisi linguistik, sebagai suatu simbol linguistik dan simbol budaya (Purwanto, 2006). 
Bahasa merupakan lambang yang sempurna dari pengalaman manusia, bahasa tidak dapat dipisahkan dari tindakan, dan bahasa merupakan wahana ungkapan yang nuansanya sangat halus (Bright, 1947: 66). Di sinilah letak kerangka hubungan antara pikiran dan bahasa. Sebagai contoh peta-peta Indonesia yang dahulu menjadi sumber acuan, seperti peta rupabumi (topografi), peta hidrografi yang berskala besar, adalah hasil karya orang asing. Misalnya Fort de Kock sebagai Bukittinggi, Buitenzorg (Bogor), Padangbai (Padang Baai) atau Teluk Padang di Bali, Pulobai di Bengkulu sebenarnya Pulau Baai, dan Teluk Lada di ujung Barat Jawa Barat Peper Baai.

Soepomo (2009) menuturkan bahwa kajian nama-nama dusun/pedusunan di Wilayah DIY dapat ditinjau dari segi linguistik, seperti: Ndagen, Mbantul, dan Mbandung (grammer/bois causen), bisilabik: Rejoinangun-Joinangun, Prang Wedanan Prambanan, Sekarsuli- Karsuli. Dari segi sosiolinguistik, ada nama asli: Gamol, ada compound: Pracimantara, ada yang lahir dari budaya keraton: Suryodiningratan, ada nama desa: Ngebel, Condrowangsan. Ada istilah-istilah nama kota/dusun/pedusunan/kampung yang berasal dari bahasa Belanda: Buiten Zorg- Bogor (tapi betulkah?), Klitren- Kulitrain, Jembatan Kewek (Chat Weg: Blnd) atau kewek adalah istilah Jawa, yaitu perempuan genit atau pelacur, Krekop- halaman gereja (churc/gereja), Pathuk- Part Hook, dan Petinggen- tempat pejabat tinggi. Jadi, ada nama asli desa, nama dari istilah Belanda dan sudut pandang penamaannya sangat beragam (Wawancara, Juli 2009).

Dari studi awal melalui pengamatan secara sekilas oleh penulis tentang namanama tempat di beberapa wilayah di Daerah Istimewa Yogyakarta, ditemukan data bahwa ada penamaan tempat yang bersumber dari ciri fisik (topografi), seperti Sendang, Krikilan, dan Jonggrangan; ada penamaan tempat yang bersumber dari dunia air, seperti: Kalitirto, Sumbertirto, Jogotirto, Sendangtirto, Tegaltirto; bersumber pada dunia hewan, seperti Terwilen, Sapen, dan Njaranan. Untuk penamaan Macanan ternyata salah analisisnya apabila berasal dari macan (nama hewan), yang betul terkait dengan kegiatan membaca (maca:Jw.). Pada bagian yang lain, ada tulisan yang bersumber pada dunia tumbuhan, seperti Ndodongan, Jaten, dan Mblimbingan; penamaan yang bersumber pada pekerjaan/profesi/ hasil karya, seperti Kemasan, Gamelan, Jagalan, dan sebagainya.

Penamaan tempat (toponimi) tersebut sangat bervariasi dilihat dari survei awal tadi dan belum tentu betul uraian analisis penulis tersebut. Permasalahan toponim akan semakin berkembang bila dikaji dari segi sistem kebahasaaan, motivasi dan tujuan, latar belakang sejarah dan kulturalnya.

Berdasarkan latar belakang masalah tersebut perlu dilakukan penelitian tentang sistem penamaan wilayah (pedusunan/kampung) di Daerah Istimewa Yogyakarta. Bagaimanakah bentuk-bentuk nama pedusunan/kampung tersebut, dilihat dari: ( a) bentuk morfem, (b) berdasarkan jumlah morfem, (c) jumlah suku kata, (d) pilihan kata, (e) jumlah kata, proses pembentukan kata, asal-usul dan maknanya (etimologinya). Bentuk mana yang dominan dilihat dari segi linguistik dan bagaimana dimensi antropolinguistiknya.

\section{METODE}

Metode penelitian yang digunakan adalah metode kualitatif etnografi. Metode etnografi yang dimaksud pada penelitian ini adalah metode etnografi Spradley, yaitu antropologi kognitif, yang dikenal dengan metode alur penelitian maju bertahap (The Developmental Research Sequence) (Spradley, 1997:89).

Lokasi penelitian adalah wilayah pemerintahan Propinsi Daerah Istimewa 
Yogyakarta, yang mencakup satu kota madya dan empat kabupaten, yaitu Kabupaten Sleman, Bantul, Kulan Progo, dan Gunung Kidul. Fokus penelitian akan ditentukan berdasarkan keberadaan informasi tentang nama-nama pedusunan/ kampung di wilayah pinggirandan perkotaan, yang memungkinkan data dapat ditemukan. Penentuan lokasi penelitian juga mempertimbangkan karakteristik pedusunan/kampung, seperti: daerah keraton/dalam beteng, daerah perkotaan (kota kabupaten/kota), daerah pinggiran kota kabupaten atau desa. Setelah langkah di atas, lokasi diklasifikasi menjadi dua kategori, yaitu istanasentris (Kota Yogyakarta) dan nonistanasentris/umum (Empat kota kabupaten yang lain).

Dalam penelitian ini arah kajian dimulai dari analisis data-data kebahasaan dan dikaitkan dengan analisis fenomena budaya yang melatarbelakanginya. Nama-nama pedusunan/kampung diinventarisasi baik dari sumber lisan maupun tertulis, diseleksi, direduksi, diklasifikasi, dianalisis segi kebahasaan (struktur bentuk dan maknanya), dan dianalisis fungsi dan tujuan penamaan dilihat dari aspek-aspek sejarah, budaya dan kondisi politik/pemerintahan, bentuk benda dan lingkungan fisiknya (Ononim).

Data penelitian ini adalah nama-nama pedusunan/kampung. Sumber data dalam penelitian ini berupa sumber data tertulis, seperti: dokumen/arsip dari pemerintahan, kamus, ensiklopedia, buku-buku folklore, hikayat, babad, atau sejarah, dan sumber data lisan, yakni nara sumber (informan). Pemeriksaaan keabsahan data dilakukan dengan teknik trianggulasi, yakni trianggulasi sumber data dan trianggulasi metode.

Analisis data yang digunakan adalah model analisis interaktif. Sebuah model analisis yang melibatkan tiga komponen, yakni reduksi data, sajian data, dan penarikan simpulan dan verifikasi (Sutopo, 2006: 119-122). Ketiga komponen analisis tersebut dilakukan bersamaan dengan pengumpulan data. Jadi, pada saat pengumpulan data berjalan, sekaligus tiga komponen analisis itu juga dikerahkan. Setiap simpulan sementara sudah diperoleh maka proses pengumpulan data terus berjalan sampai simpulan tersebut dipertimbangkan mantap. Prosedur pelaksanaan tersebut dilakukan secara berulang-ulang sebagaimana membentuk sebuah siklus.

Analisis bersifat induktif, artinya analisis di sini tidak bertujuan untuk membuktikan teori ataupun hipotesis. Teori dan simpulan dibentuk dari beragam data yang benar-benar ditemukan di lapangan dan dibahas secara multiperspektif (Sutopo, 2006: 119-122). Selanjutnya hasil kerja analisis ketiga komponen tersebut ditindaklanjuti dengan analisis linguistik dengan metode agih dengan teknik bagi unsur langsung (BUL) (Sudaryanto, 1993) dan analisis sejarah-budaya dengan metode historis kultural (Sarah via Pradana, 2007; Sumarsih, 1981).

\section{HASIL DAN PEMBAHASAN}

Penyajian hasil penelitian menggunakan dua model, yaitu penyajian informal dan penyajian formal (Sudaryanto, 1993: 144-157). Uraian dari segi linguistik akan disampaikan secara berturut-turut aspek: satuan pembentuk toponim berupa: kata dasar/bentuk tunggal, kata jadian/bentuk kompleks, frase atau klausa, kata monomorfemis atau polimorfemis, jumlah suku kata, kategori kata atau frase bernuansa khusus/keraton atau sehari-hari, terdiri atas satu kata atau dua kata, masingmasing aspek berapa frekuensinya, serta dilengkapi dengan proses pembentukan dan etimologinya. Jumlah toponim nama pedusunan/kampung di wilayah istanasentris 82 buah dan 85 buah di wilayah nonistanasentris. Uraian selengkapnya dalam tabel frekuensi dan contoh pedusunan/kampung disajikan pada Tabel 1, Tabel 2 dan Tabel 3. 
Tabel 1. Rekapitulasi Penamaan Pedusunan dari Aspek Wujud Satuan Lingual, Jumlah Morfem, dan Jumlah Suku Kata

\begin{tabular}{|c|c|c|c|c|c|c|c|c|c|}
\hline \multirow{3}{*}{ No. } & \multirow{3}{*}{$\begin{array}{l}\text { Klasifi- } \\
\text { kasi } \\
\text { wilayah }\end{array}$} & \multicolumn{8}{|c|}{ Kategori } \\
\hline & & \multicolumn{3}{|c|}{ Wujud Satuan Lingual } & \multicolumn{2}{|c|}{ Jumlah Morfem } & \multicolumn{3}{|c|}{ Jumlah Suku Kata } \\
\hline & & $\begin{array}{c}\text { Kata } \\
\text { tunggal }\end{array}$ & $\begin{array}{c}\text { Kata kom } \\
\text { pleks }\end{array}$ & frase & $\begin{array}{l}\text { Mono- } \\
\text { morfemis }\end{array}$ & $\begin{array}{l}\text { Polimor } \\
\text {-femis }\end{array}$ & $\begin{array}{c}\text { Satu } \\
\text { Suku } \\
\text { kata }\end{array}$ & $\begin{array}{c}\text { Dua Suku } \\
\text { Kata }\end{array}$ & $\begin{array}{c}\text { Lebih dari } \\
\text { dua suku } \\
\text { kata }\end{array}$ \\
\hline 1. & $\begin{array}{l}\text { Istana } \\
\text { sentris }\end{array}$ & $\begin{array}{c}7 \text { data } \\
(8,53 \%)\end{array}$ & $\begin{array}{c}68 \text { data } \\
(82,92 \%)\end{array}$ & $\begin{array}{c}7 \text { data } \\
(8,53 \%)\end{array}$ & $\begin{array}{c}7 \text { data } \\
(8,53 \%)\end{array}$ & $\begin{array}{c}75 \\
(91,4 \%)\end{array}$ & - & $\begin{array}{c}8 \text { data } \\
(9,76 \%)\end{array}$ & $\begin{array}{l}74 \text { data } \\
(90,24 \%)\end{array}$ \\
\hline 2. & $\begin{array}{l}\text { Nonista- } \\
\text { nasentris }\end{array}$ & $\begin{array}{c}20 \text { data } \\
(23,52, \%)\end{array}$ & $\begin{array}{l}56 \text { data } \\
(65,88 \%)\end{array}$ & $\begin{array}{c}9 \text { data } \\
(10,58 \%)\end{array}$ & $\begin{array}{c}20 \text { data } \\
(23,52 \%)\end{array}$ & $\begin{array}{c}65 \text { data } \\
(76,48 \%)\end{array}$ & - & $\begin{array}{c}7 \text { data } \\
(8,23 \%)\end{array}$ & $\begin{array}{l}78 \text { data } \\
(91,76 \%)\end{array}$ \\
\hline
\end{tabular}

Tabel 2. Rekapitulasi Penamaan Pedusunan dari Aspek Pilihan Kata dan Jumlah Kata

\begin{tabular}{|c|c|c|c|c|c|c|}
\hline \multirow{3}{*}{ No. } & \multirow{3}{*}{$\begin{array}{c}\text { Klasifikasi } \\
\text { wilayah }\end{array}$} & \multicolumn{5}{|c|}{ Kategori } \\
\hline & & \multicolumn{2}{|c|}{ Pilihan Kata } & \multicolumn{3}{|c|}{ Jumlah Kata } \\
\hline & & $\begin{array}{c}\text { Kosa-kata umum/ } \\
\text { sehari-hari }\end{array}$ & $\begin{array}{l}\text { Kosakata khu- } \\
\text { sus }\end{array}$ & Satu kata & Dua Kata & Tiga kata \\
\hline 1. & Istana & 33 data & 49 data $(59,75 \%)$ & 68 data & $14(17.07)$ & \\
\hline & sentris & $(40,24 \%)$ & & $(82,92 \%)$ & & \\
\hline 2. & $\begin{array}{c}\text { Nonistana } \\
\text {-sentris }\end{array}$ & $\begin{array}{c}69 \text { data } \\
(81,17 \%) \%)\end{array}$ & 16 data $(18,82 \%)$ & $\begin{array}{l}65 \text { data } \\
(76,48 \%)\end{array}$ & $\begin{array}{l}20 \text { data } \\
(23,52 \%)\end{array}$ & - \\
\hline
\end{tabular}

Tabel 3. Contoh Data dan Asal-Usul Etimologi Penamaan Pedusunan

\begin{tabular}{|c|c|c|c|}
\hline No & Wilayah & $\begin{array}{l}\text { Nama pedusunan/kampung } \\
\text { dan Pola Pembentukan }\end{array}$ & Asal-usul Etimologi \\
\hline \multirow[t]{3}{*}{1} & $\begin{array}{l}\text { Istana } \\
\text { sentris }\end{array}$ & /taman/,n berupa kata asal/kata tunggal, & $\begin{array}{l}\text { /taman/ bermakna "tempat yang } \\
\text { ditanami bunga-bunga dan untuk } \\
\text { bersenang-senang } \quad \text { (KBBI, 2008). }\end{array}$ \\
\hline & & $\begin{array}{l}\text { 'ngadisuryan/ berasal dari }\{\mathrm{A}-(\mathrm{Ng}) \text {-an }\} \\
\text { 'tempat' + D: /adisurya/,nmenjadi } \\
\text { /ngadisuryan/,n, kata kompleks "tempat } \\
\text { tinggal Adisurya', kata majemuk, arti baru, } \\
\text { 'tempat tinggal seorang pengayom dan } \\
\text { pelindung'. }\end{array}$ & $\begin{array}{l}\text { Konfiks }[\mathrm{A}(\mathrm{Ng}) \text {-an] + /adisurya/, } \\
\text { menjadi /ngadisuryan/, 'tempat inggal } \\
\text { adisurya'. Asal D:/adisurya/,/adi/ } \\
\text { 'besar' dan surya 'matahari', BPH. } \\
\text { Adisurya, putra HB VII }\end{array}$ \\
\hline & & $\begin{array}{l}\text { /kadipaten lor/, fn, berasal dari/kadipaten/ } \\
\text { dan/lor/membentuk frase nomina. Bentuk } \\
\text { /kadipaten/ berasal dari D: /adipati/ + [ka-an] } \\
\text { menjadi /kadipatian/ terus berproses menjadi } \\
\text { /kadipaten/ }\end{array}$ & $\begin{array}{l}\text { Ikadipaten Lior/, fn mempunyai makna } \\
\text { 'tempat tinggal adipati'. Konfiks \{ka-an\} } \\
\text { bermakna 'tempat tinggal'. Adipati itu } \\
\text { adalah putra mahkota, nantinya akan } \\
\text { menggantikan menjadi raja }\end{array}$ \\
\hline \multirow[t]{3}{*}{2.} & $\begin{array}{l}\text { Nonistana } \\
\text { sentris }\end{array}$ & $\begin{array}{l}\text { /Guwo/,n (gua:Jawa), kata tunggal, ' tanah } \\
\text { gunung yang berlubang besar (KPBJ, 2001) }\end{array}$ & $\begin{array}{l}\text { penamaan pedusunanGuzo tersebut } \\
\text { berlatar belakang adanya gua di } \\
\text { wilayah itu }\end{array}$ \\
\hline & & $\begin{array}{l}\text { /nanggul/, } \mathrm{v}, \text { kompleks berasal dari /tanggul/, } \mathrm{n} \\
(\mathrm{Jw})+\{\mathrm{A}-(\mathrm{N}-)\}, \text { membuat sesuatu menyerupai } \\
\text { tanggul'. /tanggul/,n gundukan tanah } \\
\text { berfungsi untuk menahan laju air }\end{array}$ & $\begin{array}{l}\text { Nanggul, v berasal dari /tanggul } /, \mathrm{n} \\
\text { bermakna tanah yang topografinya } \\
\text { lebih tinggi dari pada tanah yang ada di } \\
\text { sekitarnya.biasa untuk menahan laju air }\end{array}$ \\
\hline & & $\begin{array}{l}\text { /jojoran lor/, fn berasal dari /jojoran/ }+/ \text { lor } / / \text {. } \\
\text { Bentuk //jojoran/ berasal [jojor/ }+\{\text {-an\}. } \\
\text { Akhiran }\{\text {-an\} bermakna tempat.. }\end{array}$ & $\begin{array}{l}\text { penamaan Jojoran Lor didasarkan pada } \\
\text { keadaan topografi tanah wilayah } \\
\text { tersebut, yaitu jojor (Jw) mempunyai } \\
\text { arti 'jalan yang naik' (nanjak:Jw) }\end{array}$ \\
\hline
\end{tabular}




\section{Satuan Pembentuk Toponim}

Dari data yang dideskripsikan pada Tabel 1 dan 2, deskripsi toponim nama pedusunan/kampung dilihat dari segi linguistik, dapat dijelaskan bahwa bentuk lingual toponim nama pedusunan/ kampung di Daerah Istimewa Yogyakarta dominan dalam bentuk kata jadian atau bentuk kompleks. Berupa morfem akar yang sudah memperoleh pengimbuhan atau morfem pradasar yang sudah memperoleh pengimbuhan atau pemajemukan, sebanyak 68 data dari total $82(82,92 \%)$ di wilayah istanasentris dan 56 data dari 85 $(65,88 \%)$ di wilayah nonistana sentris. Dengan kata lain, bentuk lingual toponim berupa bentuk yang sudah mengalami proses morfologis, baik pengimbuhan atau pemajemukan, dan tidak ditemukan reduplikasi atau kata ulang, yang ada hanya duplikasi leksikal yang bukan prosede morfologis (Uhlenbeck, 1983:102) atau bentuk ulang menurut Ramlan (2001a).

Data deskripsi hasil penelitian toponim di depan menunjukkan kesesuaian dengan teori yang dirujuk, dalam hal ini proses morfologis dalam bahasa Jawa karena data penelitian ini dominan dalam bentuk bahasa Jawa. Subroto (1990:15) menyatakan bahwa perubahan dalam proses morfologis dalam bahasa Jawa menyangkut tiga hal, yaitu: ada morfem dasar atau pangkal yang diubah, ada cara tertentu untuk mengubah, dan ada bentuk baru hasil pengubahan. Selanjutnya proses perubahan tersebut mempunyai keistimewaan dalam tiga hal, yaitu: ada keteraturan cara pengubahan dengan alat yang sama, menimbulkam perubahan maknawi pada bentuk baru, dan bentuk baru hasil ubahan adalah bentuk polimorfemis. Proses perubahan itu bisa berupa afiksasi, reduplikasi, dan komposisi.

Dalam penelitian ini toponim nama pedusunan/kampung di DIY dominan berbentuk kata jadian atau bentuk kompleks. Fakta tersebut dapat dintepretasikan secara historis-kultural (antropolo- gis) bahwa pola berpikir masyarakat Yogyakarta dalam memberikan nama pedusunan/kampung berada pada tahap tataran kompleks karena bahasa adalah cermin pikiran (Linda \& Wareing, 1999). Terlebih bahwa toponim yang ditemukan ada yang dalam bentuk satuan frase tentu merupakan cermin pikiran yang lebih kompleks lagi. Toponim yang diisi oleh satuan frase merupakan temuan dalam penelitian ini dan membedakan dengan penelitian toponim-toponim sebelumnya di dalam maupun di luar negeri.

Ditinjau dari sudut semantik, dalam hubungannya dengan toponim, kata-kata atau frase memiliki kemampuan merujuk pada peristiwa, hal, barang, perkara, yang terdapat di alam nyata di luar bahasa. Kata-kata referensial sebagai simbol atau tanda memiliki hubungan atau relasi dengan segala sesuatu yang ditandainya (Lyon, 1995; Ullman, 2012). Lebih lanjut dinyatakan bahwa nama tempat (toponim) merupakan salah satu bagian dari penamaan. Penamaan itu sendiri merupakan proses pencarian lambang bahasa untuk menggambarkan objek, konsep, atau proses. Penamaan biasanya memanfaatkan perbendaharaan kata yang sudah ada, kemudian dilakukan perubahan makna atau dilakukan penciptaan kata atau kelompok kata baru. Kata-kata itu memiliki kemampuan merujuk pada peristiwa, hal-hal yang terdapat di alam nyata di luar bahasa. Nama tempat mempunyai kedudukan yang berbeda bila dibandingkan dengan kata.

Dihubungkan dengan pendapat Ramlan (2001b: 27-29) dapat dinyatakan bahwa realisasi morfem dalam rangka penamaan tempat (toponim) berwujud kata. Morfem dasar toponim dilihat dari bentuknya ada yang berupa kata dasar, termasuk bentuk tunggal dan kata yang mendapat proses atau prosede morfologis: kata berafiks, kata ulang (reduplikasi), kata gabung (kompositum), atau gabungan kata, termasuk bentuk kompleks. 
Hanya saja toponim nama pedusunan/ kampung di DIY tidak ditemukan morfem dasar toponim dalam bentuk kompleks perulangan (prosede morfologis). Hal ini bisa dikaitkan keterangan bahwa nama adalah sebuah bentuk panggilan sehingga memerlukan bentuk pendek, singkat, dan padat agar komunikasi berjalan lancar. Dengan kata lain, berlatar belakang nama panggilan dalam bahasa lisan dalam Dipodjojo (1986) perlu bentuk yang pendek. Istilah yang digunakan untuk menyebut morfem oleh Ramlan disebut satuan gramatik. Satuan gramatik bisa berupa satuan bentuk tunggal (monomorfemis) dan satuan gramatik bentuk kompleks (polimorfemis). Lebih lanjut frase adalah satuan sintaksis yang terdiri atas kelompok kata dan mempunyai makna (Ramlan, 2001:35). Uraian di atas selaras dengan pendapat Bloomfield dalam bukunya Language (dalam Boas, 1964) bahwa kata merupakan bentuk bebas yang seluruhnya terdiri atas (dua atau lebih) bentuk bebas yang lebih kecil.

Secara historis-kultural (antropologis) toponim yang berbentuk kata jadian atau bentuk kompleks dominan di wilayah istanasentris. Fakta itu dapat diartikan bahwa bentuk kompleks mencerminkan pola pikir kompleks, banyak dijumpai di wilayah istanasentris (52 data kata jadian atau bentuk kompleks dan 10 data frase atau $90,7 \%$ ), sedangkan toponim yang mengandung pola pikir sederhana (diwakili bentuk tunggal) sangat sedikit atau berkisar 7 data atau 9,2\% saja (lihat Tabel 1).

Satuan pembentuk toponim di wilayah nonistanasentris juga didominasi kata jadian atau bentuk kompleks (55 data kata jadian dan 8 data frase atau 83,9\%). Hanya saja yang berupa kata dasar atau bentuk tunggal meningkat jumlahnya (12 data atau $16 \%$ ). Kondisi demikian secara antropologis dapat diintepretasikan bahwa di wilayah nonistanasentris masih banyak masyarakat menggunakan pola berpikir sederhana dalam membentuk toponim. Bila dihubungkan dengan situasi dan kondisi geografis di mana masyarakat tinggal di wilayah nonistanasentris, yaitu jauh dari pusat kebudayaan, mereka tinggal di wilayah pinggiran, akses mereka untuk memperoleh informasi baru pasti ketinggalan. Dari logika inilah akhirnya masyarakat menggunakan pola berpikir sederhana (toponim dalam bentuk kata dasar atau bentuk tunggal).

\section{Jumlah Morfem Satuan Pembentuk Toponim}

Berdasarkan Tabel 1 dan Tabel 2 dapat dideskripsikan bahwa jumlah morfem yang digunakan untuk membentuk toponim dominan polimorfemis. Toponim tersebut terdiri atas lebih dari satu morfem. Dengan demikian, ada yang terdiri atas 2 morfem atau 3 morfem. Ternyata tidak ada toponim yang terdiri atas lebih dari tiga morfem dan hal ini merupakan temuan penelitian.

Temuan tersebut bila dihubungkan dengan kajian antropologis (bahasa sebagai alat komunikasi (lisan), yang berbunyi menyebut nama-nama yang pendek akan lebih mudah bila dibandingkan dengan menyebut nana-nama yang panjang (Dipodjodjo, 1986). Oleh karena itu, dalam komunikasi dikenal atau muncul nama panggilan. Fakta tersebut menandai bahwa nama-nama yang panjang akan sulit digunakan dalam komunikasi lisan, sementara untuk memudahkan komunikasi perlu nama-nama pendek (nama panggilan). Berarti terjawab, mengapa toponim nama pedusunan/kampung di DIY, hanya terdiri atas dua atau tiga morfem saja. Secara antropologis rupanya prinsip komunikasi yang lancar ditandai oleh bentuk bahasa yang pendek (singkat, padat, dan jelas) sudah diterapkan oleh masyarakat subjek penelitian. 


\section{Jumlah Suku Kata Nama Pedusunan/ Kampung}

Jumlah suku kata pada nama pedusunan/kampung mempunyai pengertian bahwa satuan lingual nama pedusunan/ kampung bisa berupa kata tunggal, kata kompleks, dan frase. Satuan-satuan lingual tersebut terdiri atas berapa suku kata. Apakah satuan lingual tersebut terdiri atas satu suku kata, dua suku kata, atau lebih dari dua suku kata.

Apabila dilihat Tabel 1 dan 2, deskripsi toponim nama pedusunan/kampung dilihat dari jumlah suku kata wujud satuan lingual pengisi toponim, dapat dideskripsikan bahwa jumlah suku kata satuan lingual toponim yang ditemukan dominan lebih dari dua suku kata. Tiga suku kata dan empat suku kata, dan tidak ditemukan satuan lingual nama pedusunan/kampung yang terdiri atas lima suku kata atau lebih.

Sebagai contoh /ngadisuryan/ [çâdìuÙryân] berasal dari suku kata kata: nga-di-sur-yan, yaitu empat suku kata. Pemenggalan suku kata lebih berurusan dengan pengucapan atau pelafalan. Suku kata berasal dari bunyi atau fon tersebut bergabung membentuk suku kata atau silabel sebagaimana dilafalkan atau diucapkan. Sebagai contoh/druwo/terdiri atas silabel /dru/ dan /wo/, sedangkan Sruwo terdiri atas silabel /sru/ dan /wo/. Jadi, bunyi/fon akan bergabung membentuk silabel atau suku kata. Suku atau silabel bukan satuan lingual sehingga tidak bermakna. Di sisi lain, fon yang bergabung satu dengan yang lain bisa juga membangun satual lingual, yaitu morf. Jadi, morf mempunyai makna dalam penggunaan bahasa. Dengan demikian, silabel berarti berbeda dengan morf. Dapat disimpulkan bahwa kumpulan bunyi/fon dalam toponim nama pedusunan/kampung tersebut bisa membentuk satuan lingual morf, bisa juga membentuk silabel yang bukan satuan lingual. Berikut penjelasan lewat contoh perbedaan suku kata dan morf.
Bentuk/sruwo/ sebagai contoh kata tunggal, terdiri atas dua suku kata, yaitu: sru-wo dan terdiri atas satu morfem, yaitu: \{sruwo\}. Bentuk/ngadisuryan/ sebagai kata kompleks, terdiri atas empat suku kata: nga-di-sur-yan dan terdiri atas tiga morfem, yaitu: gabungan fon yang membentuk morf, yaitu: konfiks atau imbuhan gabungan rumaket $\{\mathrm{A}-/[\mathrm{ng}]-$ an $\}+$ morfem dasar/hadisurya/ atau /adisurya/ menjadi /ngadisuryan/,n, berupa kata majemuk yang bermakna tempat tinggal pemimpin besar yang mampu melindungi rakyat. Konfiks imbuhan terbagi, yaitu di depan morfem dasar /adisurya/ bisa hadir morfem $\{\mathrm{A}-\}$ dan di belakang morfem dasar / hadisurya/ hadir morfem $\{$-an\} sehingga terdapat tiga morfem: $\{$ adi $\}+\{$ surya $\}+$ $\{\mathrm{A} / \mathrm{Ng} / \mathrm{-an}\}$.

Berikutnya adalah contoh berupa frase: /jojoran Wetan/Kulon/ terdiri atas lima suku kata, yaitu: jo-jo-ran-we-tan. Hal tersebut merupakan kajian yang baru dalam penelitian ini yaitu terkait dengan jumlah suku kata pada frase. Penelitian sebelumnya ditemukan jumlah suku kata pada kata-kata bahasa Jawa maksimal empat suku kata (Ulenbeck, 1982).

Teori berbunyi "Menyebut namanama yang pendek akan lebih mudah bila dibandingkan dengan menyebut nananama yang panjang" (Dipodjodjo, 1986). Oleh karena itu, dalam komunikasi seharihari dikenal atau muncul nama panggilan. Fakta tersebut menandai bahwa namanama yang panjang akan sulit digunakan dalam komunikasi, sementara untuk memudahkan komunikasi perlu namanama pendek (nama panggilan). Sekarang sedikit terjawab, mengapa toponim nama pedusunan/kampung di DIY, hanya terdiri atas dua, tiga, atau empat suku kata saja. Rupanya prinsip komunikasi yang lancar ditandai oleh penggunaan bentuk bahasa yang pendek atau dipendekkan (konstraksi) menurut Uhlenbeck (1982), yang bersifat singkat, padat, dan jelas sudah diterapkan oleh masyarakat subjek 
penelitian. Lebih lanjut Uhlenbeck (1982) menyatakan kontraksi adalah pemendekan dengan menghilangkan beberapa bunyi atau satu suku kata pada bentuk yang ada. Hal ini dapat diberi contoh nama pedusunan/kampung: Sekarsuli menjadi Karsuli, Lemah Abang menjadi Mahbang, Gedongkuning menjadi Dongkuning, dan Andongsari menjadi Dongsari.

\section{Pilihan Kata Pada Toponim}

Pada Tabel 1, pilihan kata pada lingkungan istanasentris dominan berupa kata-kata khusus (kata bernuansa keraton), yakni 60 data dari 79 data $(75,8 \%)$, yang terdiri atas nama kerabat keraton (istana): anak, cucu, menantu, adik, kakak, ipar, kakek, nenek, besan, dan lain-lain (kerabat atau keluarga besar raja), nama pejabat pemerintahan di keraton, nama pejabat administratif keraton, nama jabatan di keraton, nama prajurit keraton, nama profesi di lingkungan keraton, dan nama bangunan-bangunan di keraton. Sebaliknya, hanya sedikit toponim nama pedusunan/kampung berasal dari kata-kata sehari-hari/umum (33 data atau 40,24\%). Pada Tabel 2, pilihan kata di wilayah nonistanasentris dominan kata sehari-hari, yaitu 69 data $(81,17 \%)$, sedangkan kata bernuansa khusus 16 data (18,82\%).

\section{Jumlah Kata pada Toponim}

Jumlah kata pengisi toponim nama pedusunan/kampung di DIY terdiri atas satu atau dua kata dan dominan satu kata $(82,92 \%$ dan $76,48 \%)$. Tidak ada yang diisi lebih dari dua kata. Sebagai contoh: Ngadisuryan satu kata, yaitu kata berimbuhan, Kajor Wetan /kâjãr/ /wìtân/ adalah dua kata, yaitu kajor dan wetan, yaitu frase. Di samping itu, perlu juga untuk mengelompokkan nama pedusunan/kampung itu terdiri atas berapa kata, dilihat dari segi cara menulisnya. Sebagai misal: Pelemmantung /pçlçmmântÙç/ adalah satu kata karena penulisan nama pedusunan/kampung tersebut serangkai antara pelem dan mantung. Demikian pula Pringgading /prÉçgâdÉç/ adalah satu kata karena ditulis serangkai antara pring dan gading. Nama pedusunan/kampung Jagalan/jâgâlân/ Ledoksari /lçdãAsârì/ terdiri atas bentuk [jagalan] dan [ledoksari] atau Jagalan Beji terdiri atas [jagalan] dan [beji]. Jadi, nama pedusunan/kampung itu terdiri atas dua kata.

Melalui tabel toponim nama pedusunan/kampung, dapat dideskripsikan bahwa sebagian toponim nama pedusunan/kampung di DIY terdiri atas satu kata karena nama-nama pedusunan/kampung itu terdiri atas morfem-morfem yang ditulis serangkai.

\section{SIMPULAN}

Dari deskripsi hasil penelitian dan pembahasan, dapat ditarik simpulan sebagai berikut. Pertama, nama pedusunan/ kampung dominan berbentuk kata jadian/ bentuk kompleks, di samping temuan baru berbentuk frase dan klausa. Bentuk kata jadian/bentuk kompleks berupa morfem akar ditambah pengimbuhan atau morfem pradasar memperoleh pengimbuhan atau pemajemukan dan tidak ditemukan dalam bentuk perulangan (temuan). Secara antropologis nama adalah sebutan atau panggilan. Agar komunikasi berjalan lancar perlu bentuk pendek/singkat, bukan perulangan (panjang).

Kedua, berdasarkan jumlah morfem, nama pedusunan/kampung di Daerah Istimewa Yogyakarta dominan dalam bentuk polimorfemis. Bahasa cermin pikiran. Oleh karena itu, bentuk polimorfemis penamaan kampung Masyarakat Yogyakarta melibatkan pemikiran tahap kompleks karena memadukan beberapa ide sekaligus. Secara antropologis, semakin ke pinggir lokasi kampung (jauh dari pusat kebudayaan) semakin banyak bentuk monorfemis, pola berpikir masyarakatnya semakin sederhana.

Ketiga, berdasarkan jumlah suku kata, nama pedusunan/kampung berupa kata 
kompleks dan dominan berjumlah lebih dari dua suku kata, yaitu tiga atau empat suku kata dan tidak ditemukan lima suku kata atau lebih. Nama pedusunan/ kampung berupa frase terdiri atas lima suku kata. Secara antropologis, jumlah suku kata pada satuan lingual nama pedusunan/kampung berupa kata kompleks sedikit (pendek), yakni tiga atau empat suku kata dan yang berupa frase terdiri atas lima suku kata. Itupun masih dilakukan kontraksi sehingga nama tersebut menjadi lebih pendek lagi dan mudah diucapkan.

Keempat, berdasarkan pilihan kata, toponim nama pedusunan/kampung di DIY dominan berupa kata-kata bernuansa khusus/keraton di wilayah istanasentris, sedangkan di wilayah nonistanasentris dominan berupa kata yang bernuansa sehari-hari.

Kelima, berdasarkan jumlah kata, toponim nama pedusunan/kampung di DIY dominan terdiri atas satu kata. Nama pedusunan/kampung sebagai bagian dari sebutan/label/simbol, cenderung menggunakan bentuk yang singkat, bahkan muncul nama panggilan (bahasa lisan) sehingga bentuknya lebih pendek. Secara antropologis fakta hasil penelitian toponim tinjauan linguistik menegaskan bahwa pola pikir, pandangan hidup, dan logika bahasa mendasari toponim yang dihasilkan.

\section{UCAPAN TERIMA KASIH}

Artikel ini disarikan dari Disertasi yang berjudul Sistem Toponim Pedusunan/ Kampung di Daerah Istimewa Yogyakarta pada Program Pascasarjana Universitas Sebelas Maret Surakarta. Ucapan terima kasih disampaikan kepada Prof. Dr. H. D. Edi Subroto, selaku Promotor dan Prof. Dr. Heddy Shri Ahimsa Putra, selaku Kopromotor atas segala bimbingan, perhatian, dan kesabaran selama proses penyelesaian penelitian dan penulisan disetasi. Ucapan terima kasih juga disam- paikan kepada Tim Penilai Kelayakan dan Dewan Penguji atas saran dan masukan untuk penyempurnaan hasil penelitian ini.

\section{DAFTAR PUSTAKA}

Bright, Brown. 1947. Studies in Linguistics Relativity. Dalam Headings in Social Psychology, E.E. Maccoby, dkk. (ed.). New York: Hold Rinehart and Winston.

Boas, Franz. 1964. Linguistics and Ethnology. Dalam Dell Hymes (Ed.) Language in Cultural and Society. New York: Harper and Row.

Dinas Pariwisata, Seni, dan Budaya. 2007. Toponim Kota Yogyakarta. Yogyakarta: Jaranitra.

Dipodjodjo, Asdi. 1986. Komunikasi Lisan. Yogyakarta: Andi Offset.

Purwanto, Hari. 2006. Kebudayaan dan Lingkungan dalam Perspektik Antropologi.Yogyakarta: Pustaka Pelajar.

Koentjaraningrat. 1994. Pengantar Ilmu Antropologi Jilid I. Jakarta: AksaraBaru.

Koentjaraningrat. 1997. Pengantar Antropologi Jilid II. Jakarta: Rineka Cipta.

Linda and Wareing. 1999. Language, Society, and Power. New York: Routledge.

Lyon, John. 1995. Pengantar Teori Semantik. Jakarta: Gramedia.

Pradana, M. Satya. 2007. "Nama-nama Jalan di Wilayah Krapyak Kulon". Skripsi. Jurusan Antropologi, UGM.

Ramlan. M.2001a.Sintaksis: Suatu Tinjauan Deskripstif. Yogyakarta: CV Karyono.

Ramlan. M.2001b. Morfologi: Suatu Tinjauan Deskripstif. Yogyakarta: CV Karyono.

Ramlan. M. 1985. Morfologi: Suatu Tinjauan Deskripstif. Yogyakarta: CV Karyono.

Spradley. 1997. Ethnographi Komunikasi. Jakarta: Djambatan.

Subroto, Edi D. 1990. Tata Bahasa Deskriptif Bahasa Jawa. Jakarta: Dikti.

Sumarsih, Sri. 1981. "Asal-Usul Nama pedusunan/kampung yang Ada Hubungannya dengan Keraton Kasunanan 
Surakarta". Jaranitra Yogyakarta, Patra Widya, Nomor 33: 43-140.

Sutopo, HB. 2006. Metodology Penelitian

Kualitatif: Dasar Teori dan Terapannya.

Surakarta: Universitas Sebelas Maret.
Uhlenbeck. 1983. Reduplikasi dalam Bahasa Indonesia. Jakarta: Djambatan

Ullman, Stephen. 2012. Pengantar Semantik Bahasa Indonesia. Yogyakarta: Pustaka Pelajar. 